УДК [378:373.2.011.3-052]:316.72:17

DOI:

Тетяна Атрощенко, доктор педагогічних наук, доцент, дочент кафедри педагогіки дошкільної, початкової освіти та освітнього менеджменту Мукачівського державного університету

Лариса Зданевич, доктор педагогічних наук, професор, завідувач кафедри дошкільної педагогіки, психології та фахових методик Хмельницької гуманітарно-педагогічної академіі

\title{
АКСІОЛОГІЧНИЙ ПІДХІД У ФОРМУВАННІПОЛІКУЛЬТУРНОЇ КОМПЕТЕНТНОСТІ МАЙБУТНІХ ВИХОВАТЕЛІВ ЗАКЛАДІВ ДОШКІЛЬНОЇ ОСВІТИ
}

Стаття розкриває потениіал аксіологічного підходу у формуванні полікультурної компетентності майбутніх вихователів закладів дошкільної освіти. Проаналізовано дефініції понять “иінність”, “полікультурна освіта" та “полікультурна компетентність”. Аксіологічний підхід визначено як один із провідних у процесі формування полікультурної компетентності майбутніх вихователів закладів дошкільної освіти. Визначено перелік иінностей, які відіграють провідну роль у прочесі формування полікультурной компетентності майбутніх вихователів закладів дошкільної освіти, а саме: взаємоповага, совість, честь, відповідальність, любов, співчуття, порядність, гідність. Саме на їхній основі рекомендовано формувати иіннісні орієнтації майбутніх вихователів, необхідні для здійснення професійної діяльності в поліетнічному освітньому середовищі закладу дошкільної освіти.

Ключові слова: вихователі закладів дошкільної освіти; полікультурна освіта; полікультурна компетентність; аксіологічний підхід; фахова підготовка; полікультурне освітнє середовище; цінності.

Jim. 15.

Tetiana Atroshchenko, Doctor of Sciences(Pedagogy), Associate Professor, Associate Professor of the Pedagogy of Preschool, Primary Education and Educational Management Department of Mukachevo State University Larysa Zdanevych, Doctor of Sciences (Pedagogy), Professor, Head of the Preschool Pedagogy, Psychology and Professional Methods Department Khmelnytsky Humanitarian-Pedagogical Academy

\section{ANAXIOLOGICALAPPROACH IN THE FORMATION OF MULTYCULTURAL COMPETENCE OF FUTURE EDUCATORS OF PRESCHOOL EDUCATIONAL ESTABLISHMENTS}

The article has revealed the potential of the axiological approach in the formation of multicultural competence of future educators of preschool educational establishments. In a period of complex socio-political, economic, educational and cultural changes in today's globalized society has been a reassessment of the value system, new values and ideals have been formed. Today, the integrational processes taking place in the world have posed a difficult task for the national educational system - to prepare children and youth for life in a multicultural and multinational society, to form a tolerant attitude towards people of different nationalities, languages, races, religions, to develop a culture of interethnic communication. It has been important to find new, vital values, ways to include them into the educational process of training future educators of preschool educational institutions, which are the first to form new citizens of the world.

The purpose of the article is to theoretically substantiate the potential of the axiological approach in the formation of multicultural competence of educators of preschool educational establishments.

It has been noted that the formation of pedagogical axiology as a methodological approach in understanding pedagogical phenomena helps to overcome the cultural crisis, from which, unfortunately, modern civilization has been suffering and inhibiting the development of the value sphere of the individual. The axiological approach has been defined as one of the leading in the process of formation of multicultural competence of future educators of preschool educational establishments. The list of values that play a leading role in the process of forming multicultural competence of future educators of preschool educational establishments has been determined: mutual respect, conscience, honor, responsibility, love, compassion, decency, dignity. On their basis it has been recommended

Т. Атрощенко, Л. Зданевич, 2021 


\section{АКСІОЛОГІЧНИЙ ПДХІДУ ФОРМУВАННІ ПОЛІКУЛЬТУРНОӤ КОМПЕТЕНТНОСТІ МАЙБУТНІХ ВИХОВАТЕЛІВ ЗАКЛАДІВ ДОШКІЛЬНОЇ ОСВІТИ}

to form the value orientations of future educators, necessary for the implementation of professional activities in a polyethnic educational environment of preschool educational establishments.

Keywords: educators of preschool educational institutions; multicultural education; multicultural competence; an axiological approach; professional training; multicultural educational environment; values.

П остановка проблеми. У період складних суспільно-політичних, економічних, освітніх та культурних змін у сучасному глобалізованому суспільстві відбувається переоцінка системи цінностей, формуються нові цінності та ідеали. Інтеграційні процеси, які сьогодні відбуваються у світі, висувають перед вітчизняною системою освіти непросте завдання - здійснити підготовку дітей та молоді до життя в умовах полікультурного і багатонаціонального суспільства, сформувати толерантне ставлення до представників різних національностей, мов, рас, релігій, розвивати культуру міжнаціонального спілкування тощо. Ми повністю поділяємо погляди групи науковців у тому, що в процесі модернізації національної системи освіти необхідно спрямовувати та концентрувати зусилля всіх її учасників (від батьків до вчителів, викладачів) на розвиток аналітико-пізнавальної активності здобувачів освіти (на основі засвоєння фундаментальних ядер знань) та сприяти самопізнанню здобувачами власного “Я”. Йдеться про професійно-особистісні якості, толерантність й інші професійно значущі якості $[4,14]$.

Українська освіта $\mathrm{i}$, зокрема, система дошкільної освіти не може повністю розв'язати політичні, економічні, етнічні проблеми. Але вона може зробити істотний внесок у раннє формування багатоукладного менталітету, виховання підростаючого покоління поваги до культур різних народів. Заклади дошкільної освіти можуть допомогти дитині раніше й глибше зрозуміти, усвідомити і оцінити власну культуру. Відповідно, актуальним постає пошук нових, життєво важливих цінностей, способів їх включення в освітній процес підготовки майбутніх вихователів закладів дошкільної освіти (далі ЗДО), які найпершими покликані формувати нових громадян світу.

Переконані, що становлення педагогічної аксіології як методологічного підходу в осмисленні педагогічних явищ сприяє подоланню культурної кризи, від якої, на жаль, потерпає сучасна цивілізація, що суттєво гальмує розвиток ціннісної сфери особистості. Саме тому аксіологічний підхід вважаємо одним із провідних у процесі формування полікультурної компетентності майбутніх вихователів ЗДО.

Аналіз останніх досліджень і публікацій. Різні аспекти проблеми цінностей $є$ предметом дослідження С. Анісімова, В. Баруліна, $€$. Борінштейна, Т. Бутківської, А. Кавалерова, М. Кагана, Н. Костенко, О. Петінової, О. Плахотнюк, Є. Причепія, М. Стельмаховича та ін. У розвиток педагогічної аксіології значний внесок внесли праці І.Беха, Б. Бім-Бада, Б. Додонова, І.Зязюна, Т.Калюжної, М. Култаєвої, М. Михальченка, В. Огнев'юка, І. Радіонової, В. Розіна, В. Сластьоніна та ін. Професійна підготовка майбутніх вихователів ЗДО представлена у наукових розвідках А. Богуш, Н. Гавриш, Л. Зданевич, Т. Котик, Л. Пісоцької та ін. Актуальними для нашого дослідження $\epsilon$ праці Е. Бахічі, Г. Бейкер, Дж. Бенкса, П. Горскі, О. Гриви, О. Гуренко, Г. Дмітрієва та ін., в яких розкрито багатопланові питання полікультурної освіти.

Мета статті - теоретично обгрунтувати потенціал аксіологічного підходу у формуванні полікультурної компетентності вихователів ЗДО.

Виклад основного матеріалу. Згідно 3 філософським енциклопедичним словником, аксіологія - вчення про цінності, філософська теорія цінностей, що з'ясовує якості і властивості предметів, явищ, процесів, здатних задовольняти потреби, інтереси і бажання людей $[12,14]$.

Слід констатувати, що термін "цінність" $\epsilon$ одним із ключових понять сучасної суспільної думки, його активно використовують у філософії, соціології, психології та педагогіці для позначення об'єктів і явищ, їхніх властивостей, а також абстрактних ідей, що втілюють у собі моральні ідеали й виступають еталонами. Засвоєння особистістю цінностей суспільства і формування ціннісних орієнтацій залежить від багатьох чинників - культури, традицій, політичного, соціального та економічного середовищ, особливостей особистісного розвитку. При цьому на кожному етапі розвитку можуть домінувати як суспільні, так і особистісні цінності. Серед типів цінностей, що привертають найбільшу увагу аксіології, першочерговими є моральні, правові, цінності наукового пізнання, людської історії, цінності, пов'язані з природою людини і сенсом її життя тощо.

Як зауважує О. Петінова, система цінностей $і$ відношень до них визначає суспільний розвиток на основі активізації фактора людини. Виступаючи інструментом соціального регулювання, цінності, на думку авторки, $\epsilon$ тією проміжною ланкою, яка пов'язує поведінку людини з їі важливими соціальними інструментами, ідеалами, інтересами 


\section{АКСІОЛОГІЧНИЙ ПДХІДУ ФОРМУВАННІ ПОЛІКУЛЬТУРНОӤ КОМПЕТЕНТНОСТІ МАЙБУТНІХ ВИХОВАТЕЛІВ ЗАКЛАДІВ ДОШКІЛЬНОЇ ОСВІТИ}

і вимогами. Вони виконують складні і різнобічні регулятивні функції стосовно до суспільства i особистості. Ця проблема виступає найважливішою частиною програми регулювання і управління в суспільстві на етапі його оновлення $[9,183]$.

Погоджуємося 3 О. Барліт у тому, що використання аксіологічного підходу у педагогічній науці є виправданим при організації таких напрямів діяльності, як: цілісний розгляд становлення особистості в нерозривній єдності соціального й екзистенційного; включенні в дослідницький простір таких феноменів, як цінність, ідеал, духовне піднесення, переживання, віра тощо; вивчення не абстрактної, а конкретної людини у конкретних історико-культурних умовах життя, повсякденних формах функціонування, зокрема в освіті як невід’ємному атрибуті людського буття і в конкретних геокультурних умовах [1, 27].

Аксіологічний підхід, на думку Р. Винничук, дає змогу розглядати освіту як соціальнопедагогічний феномен, що знаходить відображення в основних його ідеях: універсальність і фундаментальність гуманістичних цінностей, єдність цілей і засобів, пріоритет ідеї свободи. У структурі ціннісних імперативів змісту сучасної освіти, поряд із завданнями освоєння накопиченої суспільством культури, особливе місце посідає формування ціннісного ставлення до природного і соціального середовища, власного здоров'я, зміна творчого потенціалу людини, розвиток її здібностей перетворювати існуючу дійсність $[2,94]$.

Виходячи з аксіологічних ідей, О. Олейнікова виділяє такі культурно-гуманістичні функції освіти: розвиток духовних сил, здібностей і умінь, які дають можливість людині долати життєві труднощі; формування характеру і моральної відповідальності в ситуаціях адаптації до соціального i природного середовища; забезпечення можливостей для особистісного й професійного росту і здійснення самореалізації; оволодіння засобами для досягнення свободи, особистої автономії, щастя і здоров'я; створення умов для саморозвитку творчої індивідуальності особистості і розкриття їі духовних потенцій [8].

Акцентуємо увагу на тому, що в аксіологічному аспекті основу професійної культури майбутніх вихователів ЗДО становлять педагогічні цінності. Зокрема, В. Гриньова стверджує, що педагогічні цінності є стійкими орієнтирами, за якими студент співвідносить своє життя і педагогічну діяльність, а їхню основу становлять саме духовні цінності $[3,49]$. Основними педагогічними цінностями сучасного вихователя ЗДО Л. Загородня вважає, по-перше, людські (дитина як головна педагогічна цінність, і педагог, здатний до їі розвитку, співпраці 3 нею, соціального захисту, допомоги і підтримки іiі індивідуальності, творчого потенціалу), подруге, духовні (сукупний педагогічний досвід людства, відображений у педагогічних теоріях і способах педагогічного мислення, спрямований на формування особистості дитини, по-третє, практичні (способи практичної педагогічної діяльності, перевірені практикою освітньовиховної системи, педагогічні технологіï), почетверте, особистісні педагогічні здібності, індивідуальні особливості особи педагога як суб'єкта педагогічної культури, педагогічного процесу і власної життєтворчості, які сприяють створенню особистісно-гуманної взаємодії [6, 11-12].

На основі грунтовного аналізу наукових праць 3 досліджуваної проблеми аксіологічний підхід в освіті вважаємо провідним у процесі професійної підготовки майбутніх вихователів ЗДО, оскільки характеризується конкретним спрямуванням на розвиток ціннісних орієнтацій.

Для нашого дослідження важливим $є$ достатній рівень сформованості полікультурної компетентності майбутніх вихователів ЗДО, вважаємо за доцільне розкрити сутність “полікультурної освіти” і проаналізувати цінності, які становлять їі базис.

Якщо розглядати освіту як певне надбання особистості, що закладене в психіці суб'єкта, належить його індивідуальній культурі, формується в процесі спілкування з іншими людьми та в процесі надбання особистого досвіду пізнання світу, то можна стверджувати, що освіта залежить від середовища, в якому відбувається розвиток людини, і як наслідок, визначає індивідуальний контекст іiі світосприйняття. Виходячи 3 цього, освіта здобувається у процесі взаємодії особистості з культурою спільноти, тому що більше людина отримує знань про світову культуру, то збільшуються перспективи іiі індивідуальної освіти $[11,29]$. Оскільки Україна є багатонаціональною державою, то йдеться про полікультурне середовище, яке суттєво впливає на всі сторони життєдіяльності людини i, зокрема на їі освіту, надаючи їй полікультурного змісту.

Цілком погоджуємося 3 А. Шафріковою 3 приводу того, що полікультурна освіта $\epsilon$ взаємозв'язком різних культурних середовищ у сферах освіти. Розкриваючи сутність полікультурної освіти, авторка підкреслює, що вона спрямована на збереження й розвиток усього різноманіття культурних цінностей, норм, зразків і форм діяльності, чинних у суспільстві, та грунтується на принципах діалогу і взаємодії різних культур [14]. Дж. Померін (G. Pomerin) визначає полікультурну освіту як педагогічну відповідь на 


\section{АКСІОЛОГІЧНИЙ ПДХІДУ ФОРМУВАННІ ПОЛІКУЛЬТУРНОӤ КОМПЕТЕНТНОСТІ МАЙБУТНІХ ВИХОВАТЕЛІВ ЗАКЛАДІВ ДОШКІЛЬНОӤ ОСВІТИ}

виклики мультикультурного суспільства, як відкриту діяльнісно орієнтовану концепцію, що сприймає всі суспільні зміни та ініціює інноваційні процеси. Автор бере до уваги ідею визнання індивідуальних відмінностей кожної особистості й вважає полікультурну освіту відкритою до нових знань і досвіду [15, 41].

Г. Дмитрієв слушно зауважує, що багато дослідників називають мультикультурною або полікультурною освітою те, що, по суті, $\epsilon$ поліетнічною освітою, тобто відображає питання, пов'язані з нормалізацією відносин між етнічно різними групами й індивідами. У полікультурній освіті дослідник вбачає не тільки “спосіб протистояти расизму, упередженням, упередженості, етноцентризму, ненависті, заснованої на культурних відмінностях", а й “педагогічну спробу допомогти зрозуміти свою культуру, роль узагальнень та стереотипів у комунікації між різними культурами, усвідомити своє “Я” $[5,61]$. У нашому дослідженні важливого значення набуває висунуте Г. Дмитрієвим теоретичне положення про багатокультурність як важливу складову професіоналізму майбутнього вихователя. Виходячи $з$ цього положення, студенти різних спеціальностей, майбутні фахівці “повинні вміти працювати з різними у культурному відношенні людьми, правильно розуміти людську відмінність, бути толерантними до них, вміти установлювати своїми особистими діями і словами культурний плюралізм у суспільстві” $[5,70]$.

Вважаємо, що полікультурна компетентність $є$ однією з першочергових вимог полікультурної освіти і водночас, показником професіоналізму майбутніх вихователів ЗДО. Так, полікультурна компетентність трактується І. Соколовою та О. Івашко як цілісне, інтегративне, багаторівневе особистісне новоутворення, що є результатом професійної підготовки особи у закладі вищої освіти, успішність якої зумовлена сукупністю сформованих у фахівця компетенцій, які сприяють соціалізації особистості, формуванню в неї світоглядних та науково-професійних поглядів, формуванню педагогічної творчості та майстерності, визначають успішність професійної діяльності, здатність до самореалізації, саморозвитку та самовдосконалення упродовж життя. Особі зі сформованою полікультурною компетентністю властиві цінні орієнтації, філологічна культура, набутий досвід взаємодії 3 іншими людьми $[10,95]$.

Обираючи аксеологічний підхід задля формування полікультурної компетентності майбутніх вихователів ЗДО, ми послуговувалися думкою В.Чайки про те, що у методологічній площині аксіологічний підхід грунтується на засадах педагогічної аксіології як напряму в освітніх дослідженнях, що безпосередньо стосується аналізу змісту педагогічних ідей, теорій і концепцій, з огляду на їхню відповідність чи невідповідність потребам індивіда та суспільства. Тобто аксіологізація навчання забезпечує зміщення наголосів із зовнішніх аспектів управління процесом формування знань, умінь і навичок на “внутрішні фактори активізації ціннісно-смислової сфери, самоорганізації навчальнопізнавальної діяльності студентів” $[13,49]$.

Важливим для нашого дослідження $є$ твердження А. Кир'якової, згідно з яким аксіологічний підхід у вищій освіті, вибудовуючи “людський вимір”, забезпечує визначення перспектив власного становлення, потенціалу особи як “меж можливого" [7, 7], ідеалу, якого особистість має прагнути в процесі самовиховання, самобудівництва. Саме ці положення лежать в основі процесу формування полікультурної компетентності, яка потребує від майбутнього фахівця дошкільної освіти постійної саморефлексії з огляду на вимоги полікультурної освіти. Відповідно, акцентуємо увагу на тому, що майбутні вихователі, які здійснюватимуть свою професійну діяльність в поліетнічному освітньому середовищі, повинні ще під час навчання у закладі вищої освіти оволодіти всіма надбаннями світової культури й загальнолюдськими цінностями. Як доводять науковці, “розвиток світової цивілізації потребує розширення ролі та значення дисциплін гуманітарного циклу у формуванні загальнолюдських цінностей і гуманістичних орієнтацій особистості. Розуміння цінностей іншої культури допомагатиме майбутнім фахівцям уникати труднощів комунікації, сприятиме формуванню полікультурних поглядів" $[11,158]$.

Висновки та перспективи подальших досліджень. Підсумовуючи зазначене вище, цілком переконані в тому, що процес формування полікультурної компетентності має аксіологічну спрямованість, яка передбачає формування толерантного, дружнього ставлення до культурних цінностей свого та інших етносів, носіїв інших культур, готовності до прийняття й конструктивного діалогу культур в етнічному розмаїтті тощо. У практичному аспекті аксіологічний підхід дає змогу визначити перелік цінностей, що відіграють провідну роль під час формування полікультурної компетентності майбутніх вихователів ЗДО. До спектру цінностей відносять взаємоповагу, совість, честь, відповідальність, співчуття, порядність, гідність тощо. Саме на такий iї спектр будемо робити 


\section{АКСІОЛОГІЧНИЙ ПДХІДУ ФОРМУВАННІ ПОЛІКУЛЬТУРНОӤ КОМПЕТЕНТНОСТІ МАЙБУТНІХ ВИХОВАТЕЛІВ ЗАКЛАДІВ ДОШКІЛЬНОӦ ОСВІТИ}

головний акцент під час організації освітнього процесу в 3ВО й на основі них будуть формуватися ціннісні орієнтації майбутніх вихователів, необхідні для здійснення професійної діяльності в поліетнічному освітньому середовищі закладу дошкільної освіти. Вважаємо, що для ефективного формування полікультурної компетентності майбутніх вихователів ЗДО, в рамках аксіологічного підходу, необхідно розробити і запровадити модель сучасного вихователя ЗДО, який володіє необхідними в професійній діяльності фаховими і полікультурними компетентностями, що і $є$ перспективою наших подальших досліджень.

\section{ЛІТЕРАТУРА}

1. Барліт О.О. Аксіологічний підхід в управлінні сучасними знаннями про природу. Педагогіка психологія формування творчої особистості. Запоріжжя, 2007. Вип.45. С. 23-28.

2. Винничук Р. В. Аксіологічний та культурологічний підходи як аспекти методології сучасної підготовки фахівців у вищій школі. Молодий учений. 2018. №2.2 (54.2). С. 93-96.

3. Гриньова В.М. Формування педагогічної культури майбутнього вчителя (теоретичний та методичний аспекти). Харків : Основа, 1998. 300 с.

4. Дмитренко Г., Помиткін Е., Головач Н. Формування здатних до самореалізації здобувачів освіти в умовах глобалізованого світу. Молодь і ринок. № 1(180) січень 2020. С.12-18.

5. Дмитриев Г.Д. Многокультурное образование. Москва: Народное образование, 1999. 208 с.

6. Загородня Л. П., Тітаренко С. А. Педагогічна майстерність вихователя дошкільного закладу навчальний посібник. Суми : Університетська книга, 2010.319 c.

7. Кирьякова А. В. Развитие аксиологического потенциала личности в условиях университетского образования. Вестник Оренбургского государственного университета. 2006. № 1. Том 1: Гуманитарные науки. C. 6-14.

8. Олейникова О. Д. Образовательные ценности и ценностная инверсия в культуре. Философия образования для XXI века. 2001. № 1. С. 69-79.

9. Петінова О.Б. Проблема цінності у філософії. Культура народов Причерноморья, 2002. № 36. С. $183-$ 188. URL : http://dspace.nbuv.gov.ua/handle/123456789/ $\underline{75816}$

10. Соколова I. В., Івашко О.А. Формування полікультурної компетентності у майбутніх учителівфілологів. Збірник наукових праць Бердянського державного педагогічного університету (Педагогічні науки). Бердянськ : БДПУ, 2009. № 1. С. 117-123.

11. Хомич Л. О., Султанова Л. Ю., Шахрай Т. О. Полікультурна освіта в контексті загальнокультурного розвитку особистості педагога: монографія. Кіровоград : Імекс-ЛТД, 2014. 212 c.

12. Філософський енциклопедичний словник / за ред. В. Шинкарука. Київ: Абрис, 2002. 744 с.

Молодь і ринок №2 (188), 2021
13. Чайка В. М. Основи дидактики: навч. посіб. Київ: Академвидав, 2011.240 c.

14. Шафрикова А. В. Мультикультурный подход в обучении и воспитании школьников : автореф. дис. ... канд. пед. наук. Казань, 1998. 216 с.

15. Pomerin G. Migrantenliteratur und ihre. Bedeutung fur die interkulturelle Erziehung. Zielsprache Deutsch. 1984. № 3. pp. 41-49.

\section{REFERENCES}

1. Barlit, O.O. (2007). Aksiolohichnyy pidkhid v upravlinni suchasnymy znannyamy pro pryrodu [Axiological approach in the management of modern knowledge about nature]. Pedagogy and psychology of formation of creative personality. Zaporozhye, No.45, pp. 23-28. [in Ukrainian].

2. Vynnychuk, R.V. (2018). Aksiolohichnyy ta kulturolohichnyy pidkhody yak aspekty metodolohiyi suchasnoyi pidhotovky fakhivtsiv u vyshchiy shkoli [Axiological and culturological approaches as aspects of the methodology of modern training in higher education]. Junior scientist. No.2.2 (54.2), pp. 93-96. [in Ukrainian].

3. Grinyova, V.M. (1998). Formuvannia pedahohichnoi kultury maibutnoho vchytelia (teoretychnyi ta metodychnyi aspekty) [Formation of pedagogical culture of the future teacher (theoretical and methodical aspects)]. Kharkiv, 300 p. [in Ukrainian].

4. Dmitrenko, G., Pomitkin, E. \& Golovach, N. (2020). Formuvannia zdatnykh do samorealizatsii zdobuvachiv osvity v umovakh hlobalizovanoho svitu [Formation of self-fulfilling students in a globalized world]. Youth \& market. No. 1 (180), pp.12-18. [in Ukrainian].

5. Dmitriev, G.D. (1999). Mnogokulturnoe obrazovanie [Multicultural education]. Moscov. [in Russian].

6. Zagorodnya, L.P. \& Titarenko, S.A. (2010). Pedahohichna maisternist vykhovatelia doshkilnoho zakladu [Pedagogical skills of a preschool teacher]. Sumy, 319 p. [in Ukrainian].

7. Kiryakova, A. V. (2006). Razvitie aksiologicheskogo potentsiala lichnosti $\mathrm{v}$ usloviyakh universitetskogo obrazovaniya [Development of the axiological potential of the individual in the conditions of university education]. No. 1, pp. 6-4. [in Russian]. Bulletin of the Orenburg State University.

8. Oleinikova, O.D. (2001). Obrazovatelnye tsennosti i tsennostnaya inversiya v kulture [Educational values and value inversion in culture]. Philosophy of Education for the 21st century. No.1, pp. 69-79. [in Russian].

9. Petinova, O.B. (2002). Problema tsinnosti u filosofii [The problem of value in philosophy]. Culture of the folks of the Black Sea region. No. 36, pp. 183-188. Available at: http://dspace.nbuv.gov.ua/handle/123456789/75816 [in Ukrainian].

10. Sokolova, I. V. \& Ivashko, O.A. (2009). Formuvannia polikulturnoi kompetentnosti u maibutnikh uchytelivfilolohiv [Formation of multicultural competence in future teachers of philology]. A collection of scientific works of Berdyansk State Pedagogical University (Pedagogical Sciences). Berdiansk, No. 1. pp. 117-123. [in Ukrainian].

11. Khomych, L.O., Sultanova, L. Yu. \& Shakhrai, T.O. (2014). Polikulturna osvita v konteksti zahalnokulturnoho 
rozvytku osobystosti pedahoha [Multicultural education in the context of general cultural development of the teacher's personality]. Kirovograd, 212 p. [in Ukrainian].

12. Shinkaruk, V. (2002). Filosofskyi entsyklopedychny slovnyk [Philosophical encyclopedic dictionary]. Kyiv, 744 p. [in Ukrainian].

13. Chaika, V.M. (2011). Osnovy dydaktyky: navch. posib. [Fundamentals of didactics: textbook]. Kyiv, 240 p. [in Ukrainian].
14. Shafrikova, A. V. (1998). Multikulturnyy podkhod v obuchenii i vospitanii shkolnikov [Multicultural approach in teaching and upbringing of schoolchildren]. Extended abstract of candidate's thesis. Kazan, 216 p. [in Russian].

15. Pomerin, G. (1984). Migrantenliteratur und ihre. Bedeutung fur die interkulturelle Erziehung [Literature for migrants. An importance for intercultural education]. German translatin. No.3, pp. 41-49. [in German].

Стаття надійшла до редакції 21.01.2021

\section{УДК 373.2.015:17]:502/504}

DOI:

Олена Гнізділова, доктор педагогічних наук, професор кафедри дошкільної освіти Полтавського національного педагогічного університету імені В.Г. Короленка

Оксана Станіченко, аспірант кафедри дошкільної освіти Полтавського національного педагогічного університету імені В.Г. Короленка

\section{ЕКОЛОГО-МОРАЛЬНІ ПРОЄКТИ ЯК ЗАСІБ ВИХОВАННЯ ЧУЙНОСТІ}

\section{У ДОШКІЛЬНИКІВ}

У статті розкривається необхідність впровадження волонтерського руху з метою виховання чуйності у дітей дошкільного віку як базової якості особистості, яка формується через турботу, співчуття до людей та живих істот, готовність допомагати.

Зосереджена увага на необхідності взаємодї батьків і педагогів-дошкільників закладів дошкільної освіти у вихованні моральних якостей дітей. Виокремлено ефективні форми волонтерської роботи працівників закладів дошкільної освіти і сім'ї, які використовуються в освітньому прочесі з метою виховання чуйності у дітей (шефські, сочіально-педагогічні, благодійні, патріотичні, екологічні, навчально-виховні).

Ключові слова: діти дошкільного віку; заклад дошкільної освіти; волонтерська діяльність; батьки; чуйність; еколого-моральний проєкт.

Jim. 8.

Olena Hnizdilova, Doctor of Science (Pedagogy), Professor of the Preschool Education Department Poltava Volodymyr Korolenko National Pedagogical University Oksana Stanichenko, Postgraduate Student of the Preschool Education Department Poltava Volodymyr Korolenko National Pedagogical University

\section{ECOLOGY-MORAL PROJECTS AS THE MEANS OF EDUCATING SENSITIVITY WITH PRE-SCHOOLERS}

The article studies some aspects of implementing the volunteer movement for sensitivity education as a basic characteristic of pre-schoolings, which is formed through the care, compassion for people and living beings' helpfulness. The author studies the need of implementation of volunteer activities for educating careful, responsible and kind children. The necessity of interaction between parents and pre-school institutes' teachers is considered. It is important for upbringing the moral characteristics of children. Particular attention is paid to effective forms of volunteering of employees of preschool education institutions and families, which are used in the educational process to educate children in sensitivity (mentoring, socio-pedagogical, charitable, patriotic, environmental, and educational). Possibilities of involvement of preschoolers into ecological and moral projects where kids while helping others acquire new skills, expand horizons, socialize, develop their sense of sensitivity are analyzed. The article proves this activity forms a deeply moral personality with a high level of responsibility, care, sensitivity and kindness. It is noted that the volunteer movement is a free action with a combination of several aspects: the work of creative and experienced teachers, the parents' enthusiasm and the desire of children. The author proves that preschool period is the most effective one for forming moral characteristics of personality. Analyzing the question of the need to educate the sensitivity of children the article outlines that children have a possibility to get volunteer experience since the childhood. It becomes an important element in the education process.

Keywords: pre-school children; preschool education institutions; volunteer activities; parents; sensitivity; ecology-moral project.

$\Pi$

остановка проблеми. Базовий компонент дошкільної освіти, Концепція освіти дітей раннього та

дошкільного віку та чинні програми розвитку дітей дошкільного віку орієнтують педагогів-практиків на особистісно орієнтовану сутність виховного й 